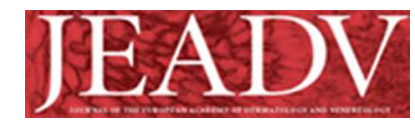

\title{
Use of biologics for psoriasis in Central and Eastern European countries
}

\begin{tabular}{|r|l|}
\hline Journal: & Journal of the European Academy of Dermatology and Venereology \\
\hline Manuscript ID: & Draft \\
\hline Manuscript Type: & Original Article \\
\hline Keywords: & psoriasis, biological drugs, drug utilization, Central and Eastern Europe \\
\hline
\end{tabular}




\title{
Title page
}

\section{Title: Use of biologics for psoriasis in Central and Eastern European countries}

\author{
Running head: Rencz F et al. Biologics for psoriasis in CEE
}

Authors: F Rencz ${ }^{1,2}$, L Kemény ${ }^{3}$, JZ Gajdácsi ${ }^{4}$, W Owczarek ${ }^{5}$, P Arenberger ${ }^{6}$, GS Tiplica ${ }^{7}$, A Stanimirović $^{8}$, M Niewada $^{9}$, G Petrova $^{10}$, LT Marinov $^{10}$, M Péntek $^{1}$, V Brodszky $^{1}$, L Gulácsi $^{1}$

1- Corvinus University of Budapest, Department of Health Economics, Fővám tér 8., H1093 Budapest, Hungary

2- Semmelweis University Doctoral School of Clinical Medicine, Üllői út 26., H-1085 Budapest, Hungary

3- Department of Dermatology and Allergology University of Szeged, Korányi fasor 6., H-6720, Szeged, Hungary

4- National Health Insurance Fund Administration of Hungary, Váci út 73/A, H-1139, Budapest, Hungary

5- Department of Dermatology, Military Institute of Medicine, Szaserów 128, 04-141 Warsaw, Poland

6- Department of Dermatology, Charles University 3rd Medical Faculty, Srobarova 50, Prague 10, 100 34, Czech Republic

7- Dermatology Clinic 2, Colentina Clinical Hospital, Carol Davila University of Medicine and Pharmacy, Sos. Stefan cel Mare nr. 19-21, sector 2, Bucharest, Romania

8- Department of Clinical Medicine, University of Applied Health Sciences, Mlinarska 38, 10000 Zagreb, Croatia

9- Department of Experimental and Clinical Pharmacology, Medical University of Warsaw, Zwirki i Wigury 61, Warsaw, Poland

10-Department of Social Pharmacy and Pharmacoeconomics, Faculty of Pharmacy, Medical University, 2 Dunav Str, Sofia, Bulgaria 


\begin{abstract}
Manuscript
Word count: 2986

Tables: 3

Figure: 1

Funding statement: None reported.

Conflict of interest: L. Kemény has been paid as a consultant of Janssen-Cilag, MSD, Pfizer and Abbvie. G.S. Tiplica was speaker at national events or received unrestricted research or educational support from MSD, Abbvie, Johnson\&Johnson, and Pfizer. A. Stanimirović has been reimbursed by Abbvie and Johnson\&Johnson for expert lectures, published professional materials and international conference attendances. M. Niewada has given lectures, as well as acted as a consultant on preparation of health technology assessment reports and market access strategies for Janssen, MSD, and Abbvie.
\end{abstract}

\title{
Corresponding author:
}

László Gulácsi M.D., Ph.D.

Corvinus University of Budapest

Fővám tér 8., H-1093 Budapest, Hungary

E-mail: laszlo.gulacsi@uni-corvinus.hu

Phone: +36 1482-5033

Fax: +36 $1482-5033$ 


\section{Abstract}

Objectives: To evaluate the use of biological agents in treatment of psoriasis and to explore country-specific differences within 6 Central and Eastern European (CEE) countries, namely Bulgaria, Croatia, the Czech Republic, Hungary, Poland, and Romania.

Methods: A literature overview on the epidemiology and disease burden of psoriasis in CEE was conducted. Numbers of patients treated with biologics were obtained from patient registries, ministries of health, national professional societies, and health insurance funds. Biological treatment rates were estimated by two different methods: (i) as a proportion of all psoriasis patients of a country (assuming a common prevalence of psoriasis $2 \%$ ) and (ii) per 100,000 population. Moreover, we provide a detailed comparison of reimbursement policies and guidelines regulating the treatment with biological drugs.

Results: On average $0.25 \%$ of all psoriasis patients, or 5 psoriasis patients out of 100,000 inhabitants are treated with biologics embedding a 14.6-fold difference between the six countries. Bulgaria, Croatia, and Poland are lagging behind the other three countries in use of biologics. The significant differences among countries cannot be explained by variations in prices of biologics or cost-effectiveness or budget impact of biologics. It seems that the time since reimbursement decision, the fewer number of reimbursed biologics, the more restrictive criteria to be eligible for reimbursed treatment in terms of baseline Psoriasis Area and Severity Index, Dermatology Life Quality Index scores, and the maximum duration of treatment allowed are responsible for the majority of the differences.

Conclusions: Spread of biologics in certain CEE countries is not hindered by the high costs of biologics, rather by the unfavourable reimbursement policies and guidelines. Presumably decision makers and payers less recognise psoriasis as a severe condition that can be successfully treated in a cost-effective manner.

Keywords: psoriasis, biological drugs, drug utilization, Central and Eastern Europe 


\section{Introduction}

Introduction of biological drugs implied the greatest advance in the management of moderate to severe psoriasis of the past decade. In 2004, etanercept was the first biological drug registered by the European Medicines Agency (EMA), followed by infliximab (2005), adalimumab (2007) and ustekinumab (2008) for the treatment of patients with moderate to severe plaque psoriasis who failed to respond to, or who have a contraindication to, or are intolerant to other systemic therapy including cyclosporine, methotrexate, or psoralen and ultraviolet-A light (PUVA). ${ }^{1,2}$ Additionally, in September 2013, biosimilar infliximab was approved by EMA in the same indications as the reference product. ${ }^{2}$

Psoriasis is a life-long condition that significantly diminishes health related quality of life (HRQOL) and may have long-term effects on patients' well-being. ${ }^{3-5}$ However, biological therapy can considerably improve clinical outcomes and HRQOL of patients. ${ }^{6-8}$ Alongside the beneficial clinical profile of biologics, high drug costs impose challenges for many countries in terms of reimbursement. An extensive study across 46 European countries in another chronic inflammatory disease (rheumatoid arthritis, RA) revealed that access to biologics is positively associated with countries' welfare; therefore, patients in lower income European countries have less access to biological drugs. ${ }^{9}$ Two previous studies, focusing on use of biologics for inflammatory rheumatic conditions and inflammatory bowel diseases, reported considerable differences in biological treatment rates between countries in the Central and Eastern European (CEE) region. ${ }^{10,11}$ Nevertheless, no evidence is available from CEE in this area concerning psoriasis. Considering the differences in economic performance across CEE, one would expect more psoriasis patients treated with biologics in higher-income countries. Either it is unclear whether the high costs of biologics are per se responsible for the low treatment rate of certain countries, or do other factors underpin the differences. In the next years, a series of biosimilar drugs are expected to be registered which offer price advantage compared to the original drugs. Thus, the increasing penetration of biosimilars may substantially modify the entire biological drug market, especially in CEE.

The purpose of this paper is, therefore, to provide an overview on the current use of biological drugs for the treatment of psoriasis patients in $6 \mathrm{CEE}$ countries, namely Bulgaria, Croatia, the 
1

2

3

4

5

6

7

8

9

10

11

12

13

14

15

16

17

18

19

20

21

22

23

24

25

26

27

28

29

30

31

32

33

34

35

36

37

38

39

40

41

42

43

44

45

46

47

48

49

50

51

52

53

54

55

56

57

58

59

60

Czech Republic, Hungary, Poland, and Romania. First, we summarise the available literature data on the epidemiology and disease burden of psoriasis in CEE. Secondly, we provide country-specific utilisation data on biologics in psoriasis in the six CEE countries and compare reimbursement policies and guidelines regulating the treatment with biological drugs. Third, we investigate and discuss the potential reasons for inter-country differences and set against other selected chronic systemic inflammatory diseases from CEE. 


\section{Methods}

\section{Epidemiology and disease burden}

A Medline-based literature review on the epidemiology and disease burden of psoriasis in CEE was conducted until the $31^{\text {st }}$ October 2014. In addition, authors provided data regarding ongoing studies and conference abstracts available on these topics from their own countries.

\section{Biological treatment rates}

Number of patients with biological treatment was obtained from different sources by country such as patient registries, health insurance databases, ministries of health, and national professional societies. Treatment rates were estimated by two different methods: (i) patients treated with biologics as a proportion of all psoriasis patients of a country and (ii) patients treated with biologics per 100,000 inhabitants. The latter method filters out potential bias due to the unknown country-specific epidemiology. Population data used were obtained from Eurostat Statistics Database. ${ }^{12}$ Correlation between health expenditure (retrieved from The World Bank Databank ${ }^{13}$ ) and the number of psoriasis patients on biological treatment was analysed for each country.

\section{Reimbursement guidelines and policies}

Data on reimbursement guidelines and policies were gathered through document analysis and pooling of country expertise. A common set of questions and issues, that pertains the regulation on use of original biologics and as well biosimilars, was sent out to experts in the six countries. Data were further validated and refined through consultation with other CEE Health Technology Assessment (HTA) experts and policy-makers, and through discussions among the authors. 


\section{Results}

\section{Epidemiology}

We identified three studies that investigated the epidemiology of psoriasis in the CEE region, so far. ${ }^{14-16}$ Prevalence of psoriasis among adults was assessed only in Croatia. A nationwide study (year 1989) reported prevalence of adult psoriasis $1.55 \%$ and a study from Karlovac region (year 1991) observed a prevalence of $0.75 \% .{ }^{14,15}$ In Romania (year 1999), prevalence of psoriasis was noted $0.25 \%$ among Romanian schoolchildren aged 6-12 years. ${ }^{16}$

Nevertheless, up-to-date country-specific incidence and prevalence data including all agegroups from the CEE countries are still lacking. Thus, we had to rely on estimations in our analyses. No evidence was found supporting that a difference in epidemiology of psoriasis within CEE exists; therefore, assuming a common prevalence of $2 \%$ for all the six countries (prevalence in Europe varies between $0.73 \%$ and $2.9 \%$ ) ${ }^{17}$ we estimated that in 2013, more than 1.8 million people lived with psoriasis in the six countries (Table 1).

\section{Disease burden of psoriasis}

Of the four psoriasis cost-of-illness studies that have been carried out in CEE countries and presented in 5 publications (Table 2), only one study from Hungary has been published as a full-text paper in an English-language peer-reviewed journal, findings from other countries were merely published as conference abstracts. ${ }^{18-22}$ Although the four studies had similar aims, direct comparison of the results is hampered by the different inclusion criteria, unknown proportion of patients on biologics, and costing methods.

\section{Number of patients on biologics}

A total of 4,591 psoriasis patients are receiving biologics in more than 73 centres of the six selected countries which is estimated to be $0.25 \%$ of all psoriasis patients (Table 1). On average 5 psoriasis patients out of 100,000 inhabitants are treated with biologics embedding a 1.1-14.6-fold difference between the six countries. Bulgaria, Croatia, and Poland are lagging behind the other three countries in use of biologics (Figure 1). 
A moderate correlation between number of patients treated with biologics per 100,000 inhabitants and countries' total expenditure on health revealed ( $r=0.50, \mathrm{p}=0.802)$; however, it was not significant due to the small number of countries involved. Remarkably, Romania treats on average 7.9 patients per 100,000 inhabitants despite its rather low per capita health expenditure (\$420). By contrast, as a respect of the higher per capita health expenditure of the Czech Republic $(\$ 1,432)$, on average 11.2 patients per 100,000 population, receiving biologics seems few.

\section{Reimbursement of biologics}

Reimbursement of biological drugs for the treatment of psoriasis started the earliest in the Czech Republic (2005), Hungary (2006), and Romania (2010), while in Bulgaria, Croatia and Poland only in 2013-2014 (Table 3). Currently, biologics are reimbursed in all the six countries and are covered without co-payment for the patients. However, in Bulgaria the National Health Insurance Fund and the pharmaceutical companies share financing on 75/25 (Table 3). In the six countries, all the four aforementioned original biologics are reimbursed, with the exception of infliximab in Poland and ustekinumab in Romania.

In 2014, biosimilar infliximab drugs were begun to be marketed in Bulgaria, the Czech Republic, Hungary, and Romania, and are reimbursed at the same level as the original drug. Nevertheless, the introduction is lagging in Croatia, Poland, and Romania.

\section{Reimbursement guidelines}

The six countries apply similar clinical eligibility criteria for reimbursement regarding biological therapy based on the recommendations of the European-S3 Guidelines ${ }^{1,23-25}$ Biologics are recommended in moderate to severe psoriasis patients who meet certain eligibility criteria expressed in Psoriasis Area and Severity Index (PASI), and/or Body Surface Area (BSA) and/or Dermatology Life Quality Index (DLQI) after being treated for at least 6 months with traditional systemic therapy or in case of these are not tolerated or contraindicated. ${ }^{1}$ However, in financial guidelines, severity scores required to be eligible for reimbursed treatment are different from those in professional guidelines. ${ }^{1,26}$ In Bulgaria (PASI $>20$ or $\mathrm{BSA}>20$ ), Croatia (PASI $>15$ and/or $\mathrm{BSA}>15$ and/or DLQI $>15)$, and Poland $(\mathrm{PASI}>18, \mathrm{DLQI}>10$, and $\mathrm{BSA}>10)$ eligibility criteria are rather restrictive and only patients 
with higher severity scores (and worse health status) are allowed to treat with biologics, whereas in the Czech Republic, Hungary and Romania, criteria are closer to those in the European-S3 Guidelines (Table 3). ${ }^{1}$ In all countries, but Poland, first assessment of treatment effect is required at week 12 after the initiation of the biological therapy.

In most countries, maintenance therapy is allowed for patients who reach a response of $\geq 50 \%$ reduction in PASI, and in addition $\geq 5$ points improvement in DLQI. Duration of treatment is unlimited, except for Poland, where adalimumab and ustekinumab can be applied up to 48 weeks and etanercept up to 24 weeks, respectively.

In all the six countries, switch between different biological substances (both original and biosimilar, where applicable) is allowed, if adverse events or inefficiency develop. 


\section{Discussion}

This paper concerned the use of biological therapy to treat psoriasis in six CEE countries. We found that on average $0.25 \%$ of all psoriasis patients, or 5 psoriasis patients out of 100,000 population are treated with biologics in CEE. Proportion of patients treated within the six countries varied as follows: Bulgaria $0.06 \%$, Croatia $0.19 \%$, the Czech Republic 0.56\%, Hungary $0.63 \%$, Poland $0.04 \%$, and Romania $0.39 \%$. Similarly, in other chronic inflammatory conditions, great heterogeneity was noted between CEE countries varying between $1.3-10 \%$ in rheumatoid arthritis (RA), and $0.7-19.1 \%$ in Crohn's disease (CD) (6 countries were considered: Bulgaria, the Czech Republic, Hungary, Poland, Romania, and Slovakia). ${ }^{10,11}$

\section{Comparison with the PSONET countries}

Registry to follow up psoriasis patients treated with biologics has been established in Croatia, the Czech Republic, Hungary, and in Poland, so far. However, they are not incorporated in the greatest psoriasis registry network, the PSONET (http:/www.psonet.eu) which is a collaborative network between independent disease registries for patients receiving conventional or biological systemic therapy for psoriasis. ${ }^{27,28}$ Currently, PSONET contains data on more than 20,000 patients from 10 Northern and Western European countries, Australia, and Israel. ${ }^{29,30}$ In Germany, between 2004-2007 according to an analysis of psoriasis patients' data retrieved from the statutory health insurances joined to PSONET, biological therapy was given to approximately in $0.1 \%$ of all psoriasis patients. ${ }^{31} \mathrm{~A}$ few years later, in 2010, biological treatment rates in the PSONET countries were estimated as follows: Germany $0.25 \%$, UK $0.2 \%$, Denmark $0.2 \%$, Italy $<1 \%$, and Sweden $1.6 \%{ }^{27}$ Treatment rates described in CEE and in the PSONET registries are not comparable due to the different years of data collection. However, the number of patients on biologics has presumably increased since 2010; therefore, we anticipate that a treatment gap between the Western European and CEE countries exists.

\section{Inter-country differences within $\mathrm{CEE}$}

A 1.1 to 14.6-fold difference between the six countries in use of biologics was found; Bulgaria, Croatia, and Poland are lagging behind the Czech Republic, Hungary, and Romania 
(Figure 1). Experts usually state that various factors may play important role in these differences such as epidemiology, total health expenditure per capita, prices of biologics, disease burden, cost-effectiveness of biologics, health care financing mechanisms, medical professionals' lobbying power, local reimbursement policy, and guidelines.

Even though there are no valid prevalence and incidence data available from CEE, we presume that inter-country variations in epidemiology cannot be per se responsible for such great differences. Neither the difference in prices of biologics explains the extent of heterogeneity observed in use (adalimumab €957-1,262, etanercept €975-1,164, infliximab $€ 481-€ 609$ (per dose national list prices). ${ }^{32}$ Total costs covered by health insurance are available only from Hungary that provide some evidences on budget impact of psoriasis. ${ }^{33} \mathrm{In}$ 2010 , average annual per patient drug costs of biologicals for psoriasis amounted to $€ 9,916$, whereas budget impact of all psoriasis patients amounted to $€ 6.8$ million, respectively. ${ }^{33} \mathrm{We}$ assume that biologics for psoriasis generate similar per patient outflow in the other six countries as well.

Total health expenditure per capita of these 6 countries $(\$ 420-1,432)$ seems to partly explain a proportion of the differences in biologic use (Figure 1). Reimbursement policies and guidelines may also obstacle the widespread use of biologics in certain countries. In Bulgaria, Croatia, and Poland start of reimbursement was delayed 7-9 years compared to the Czech Republic and Hungary which commenced the reimbursement earliest among the six countries. We believe therefore that the time since reimbursement decision is one of the factors that highly influences the treatment rates.

Besides, we found that use of biologics highly depends on eligibility criteria applied for reimbursement. The very high baseline PASI and DLQI scores required in Bulgaria, Croatia, and the somewhat lower in Poland largely explain the lower use observed in these countries (Table 3). Contrarily, countries with less restrictive criteria, such as Romania and the Czech Republic, demonstrate considerably higher treatment rates. However, despite the less favorable criteria applied in Hungary (i.e. PASI $>15$ and DLQI $>10$ ), it holds the highest treatment rate out of the six countries. In case of Poland, the limited duration of treatment reimbursed may also hamper use of biologics. Furthermore, the lack of reimbursement of infliximab in Poland and ustekinumab in Romania to treat psoriasis as well might contribute 
to the lower biologic use of these countries. In addition, Croatia and Poland do not cover biosimilar infliximab, either.

It appears therefore that use of biologics for psoriasis in certain CEE countries, such as Bulgaria, Croatia, and Poland, is not hindered by the high costs of biologics, rather by the unfavourable reimbursement policies and guidelines. And if so, these countries with their fairly unsuitable conditions for the penetration of biologics, will presumably not benefit as much from the lower-cost biosimilars either, as they could if less restrictive eligibility criteria are employed.

\section{Further challenges}

In most CEE countries, fairly similar HTA-based decision-making is applied in reimbursement that requires economic evaluations. ${ }^{34,35}$ Disease burden of psoriasis patients treated with biological therapy is unknown in CEE countries except for Hungary (Table 2). ${ }^{4,18}$ Annual individual direct costs of Hungarian moderate to severe psoriasis patients receiving biologics are in line with findings from Northern and Western Europe $(€ 13,505-18,457){ }^{36}$

As for cost-utility analyses, the international literature suggest that biologics are cost-effective alternatives for the treatment of psoriasis in countries such as UK, Germany, Sweden, Italy, the US, and Canada (£30,000-42,000/quality-adjusted life years - QALY). ${ }^{37}$ In CEE, empirical country-specific data is only available from Poland; however, cost-effectiveness results are redacted in the publicly accessible documents. ${ }^{38}$ Nevertheless, Gulácsi et al. have estimated that cost-effectiveness of biologics used in dermatology, rheumatology, and gastroenterology in CEE, noticing very similar cost/QALY results in psoriasis, RA, and CD. ${ }^{34}$ In psoriasis, multiples of per capita gross domestic product (GDP) per QALY of biologics vary between 4.13-4.79 in Bulgaria, 1.79-2.57 in the Czech Republic, 2.29-3.03 in Hungary, 2.53-3.05 in Poland, and 3.29-3.86 in Romania. ${ }^{34}$ Thus, in many cases the estimated rate exceeds the threshold of 3 times per capita GDP/QALY applied in reimbursement decision making in the Czech Republic, Hungary, Poland and Romania. ${ }^{34,35,39}$ We propose local costeffectiveness analyses in CEE countries that might facilitate the changes in reimbursement guidelines to approximate the criteria laid down in the European-S3 Guidelines. ${ }^{1}$

Patients with moderate to severe psoriasis associated with psoriatic arthritis represent a further challenge of biological therapy in psoriasis, since biologics may be effective for both the skin 
and the joint condition. In randomised controlled trials (RCT) of biologics, the achieved average health gain measured by EQ-5D at week 12-54 were $0.12-0.21$ in moderate to severe psoriasis and $0.24-0.28$ in psoriasis associated with psoriatic arthritis. ${ }^{6,740-42}$ Hence, from the viewpoint of health economics, in this patient group, cost-effectiveness of biologics might exceed that reported in psoriasis or in psoriatic arthritis separately which might support the increasing use of biologics. $^{22}$

\section{Limitations}

Possible limitation of this study is uncertainty of estimations due to lack of prevalence data from CEE. Patient numbers reported here do not include those patients who finance biologics for themselves, either those who receive the drugs within hospital budget, or under diagnosisrelated group-based (DRG) financing, or as a part of a compassionate programme of a pharmaceutical company. Nonetheless, experts state that the proportion of these patients could be considered marginal. In all countries but Hungary, patients on each substance include the switchers as well, and hence, the total number of patients is minimally overestimated. Also, comparison of country-specific reimbursement systems might be limited due to necessary simplifications.

\section{Conclusions}

To sum up, on average $0.25 \%$ of all psoriasis patients, or 5 psoriasis patients out of 100,000 inhabitants are treated with biologics. Use of biological treatment in CEE might be limited compared to Western and Northern Europe. With respect to the number of patients treated with biologics out of 100,000 inhabitants, a 14.6-fold difference was noted across the six countries; Bulgaria, Croatia, and Poland are lagging behind the other three countries in treatment rates. The significant differences among countries cannot be explained by variations in prices, cost-effectiveness, or budget impact of biologics. It seems that the time since reimbursement decision, the fewer number of reimbursed biologics, the more restrictive criteria to be eligible for reimbursed treatment in terms of baseline PASI and DLQI, and the maximum duration of treatment allowed are the factors that are responsible for the majority of the differences. Based on the available data, we presume that decision makers and payers less recognise psoriasis as a severe condition that can be successfully treated in a cost-effective manner. Our findings call for further research, including the implementation of local registries 
to follow-up patients, and disease burden and cost-effectiveness studies that may help to inform decision-makers about the true burden of psoriasis. 


\section{References}

1 Pathirana D, Ormerod AD, Saiag P, Smith C, Spuls PI, Nast A et al. European S3guidelines on the systemic treatment of psoriasis vulgaris. J Eur Acad Dermatol Venereol 2009; 23 Suppl 2: 1-70.

2 European Medicines Agency. http://www.ema.europa.eu/ema/ Accessed: 08/09/2014

3 de Korte J, Sprangers MA, Mombers FM, Bos JD. Quality of life in patients with psoriasis: a systematic literature review. J Investig Dermatol Symp Proc 2004; 9: 140-147.

4 Heredi E, Rencz F, Balogh O, Gulacsi L, Herszenyi K, Hollo P et al. Exploring the relationship between EQ-5D, DLQI and PASI, and mapping EQ-5D utilities: a cross-sectional study in psoriasis from Hungary. Eur J Health Econ 2014; 15 Suppl 1: S111-119.

5 Rencz F, Hollo P, Karpati S, Pentek M, Remenyik E, Szegedi A et al. Moderate to severe psoriasis patients' subjective future expectations regarding health-related quality of life and longevity. J Eur Acad Dermatol Venereol 2014 Dec 10. [Epub ahead of print].

6 Reich K, Segaert S, Van de Kerkhof P, Durian C, Boussuge MP, Paolozzi L et al. Once-weekly administration of etanercept $50 \mathrm{mg}$ improves patient-reported outcomes in patients with moderate-to-severe plaque psoriasis. Dermatology 2009; 219: 239-249.

7 Revicki D, Willian MK, Saurat JH, Papp KA, Ortonne JP, Sexton C et al. Impact of adalimumab treatment on health-related quality of life and other patient-reported outcomes: results from a 16-week randomized controlled trial in patients with moderate to severe plaque psoriasis. Br J Dermatol 2008; 158: 549-557.

8 Shikiar R, Willian MK, Okun MM, Thompson CS, Revicki DA. The validity and responsiveness of three quality of life measures in the assessment of psoriasis patients: results of a phase II study. Health Qual Life Outcomes 2006; 4: 71.

9 Putrik P, Ramiro S, Kvien TK, Sokka T, Pavlova M, Uhlig T et al. Inequities in access to biologic and synthetic DMARDs across 46 European countries. Ann Rheum Dis 2014; 73: 198-206.

10 Pentek M, Poor G, Wiland P, Olejarova M, Brzosko M, Codreanu C et al. Biological therapy in inflammatory rheumatic diseases: issues in Central and Eastern European countries. Eur J Health Econ 2014; 15 Suppl 1: S35-43.

11 Rencz F, Péntek M, Bortlik M, Zagorowicz E, Hlavaty T, Liwczyński A et al. Biological therapy in inflammatory bowel diseases: Access in Central and Eastern Europe. World Journal of Gastroenterology 2015; 21.

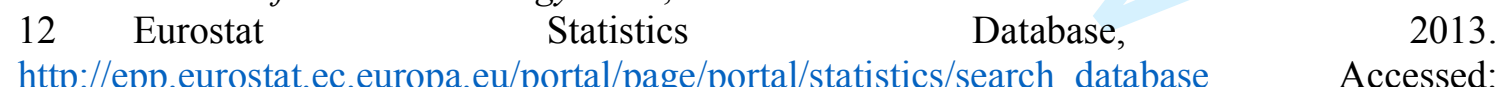

$10 / 08 / 2014$

13 World Bank Databank, 2012. http://databank.worldbank.org/data/home.aspx Accessed: 10/08/2014.

14 Barisic-Drusko V, Paljan D, Kansky A, Vujasinovic S. Prevalence of psoriasis in Croatia. Acta Derm Venereol Suppl (Stockh) 1989; 146: 178-179.

15 Del Toso-Depeder Z. Prevalence of psoriasis in the Karlovac region. Lijec Vjesn 1993; 115: $21-27$.

16 Popescu R, Popescu CM, Williams HC, Forsea D. The prevalence of skin conditions in Romanian school children. Br J Dermatol 1999; 140: 891-896.

17 Parisi R, Symmons DP, Griffiths CE, Ashcroft DM. Global epidemiology of psoriasis: a systematic review of incidence and prevalence. J Invest Dermatol 2013; 133: 377-385. 
18 Balogh O, Brodszky V, Gulacsi L, Heredi E, Herszenyi K, Jokai H et al. Cost-ofillness in patients with moderate to severe psoriasis: a cross-sectional survey in Hungarian dermatological centres. Eur J Health Econ 2014; 15 Suppl 1: S101-109.

19 Klimes J, Dolezal T. Indirect costs of moderate to severe forms of psoriasis in Czech Republic: calculation based self reported questionnaire. Value Health 2010; 13: A468.

20 Petrikova A, Klimes J, Dolezal T, Marinov L, G. P. Treatment of Patients with Moderate and Severe Psoriasis - Cost-of-Illness in the Czech Republic. Value Health 2011; 14: A305-A306.

21 Władysiuk M, Fedyna M, Bebrysz M, Mateusz H, Rutkowski J, Owczarek W et al. Indirect costs of rheumatoid arthritis, Crohn's disease and psoriasis in Poland. Health Technology Assessment International Conference 2014; June 2014: 60. http://www.htai2014.org/temp/20147448232/OR244.pdf Accessed: 08/10/2014

22 Rencz F, Brodszky V, Péntek M, Balogh O, Remenyik É, Szegedi A et al. Disease burden of psoriasis associated with psoriatic arthritis in Hungary. Orv Hetil 2014; 155: 19131921.

23 Arenberger P. Organizace biologické léčby v ČR. 1st conference of biological medicines 2010; November 12-13., 2010. http://www.prolekare.cz/odborny-event/organizacebiologicke-lecby-V-cr-11 Accessed: 10/08/2014

24 Országos Egészségbiztosítási Pénztár E, Orvosszakértői és Szakmai Ellenőrzési Főosztály. A plakkos psoriasis diagnosztikájának és kezelésének finanszírozási protokollja (eljárásrend).

2013.06.26.; http://site.oep.hu/steam/downloads/finprot_20131115/hatalyos/0626_a_plakkos_psoriasis_dia gnosztikajanak es kezelesenek finanszirozasi_protokollja.pdf Accessed: 10/08/2014

25 Kadurina $\bar{M}$, Vassileva $\bar{S}$, Gospodinov D, Dobrev H, Kazandjieva J, Mateev G et al. Guidelines for the Treatment of Psoriasis by Biological Products of Bulgarian Dermatological Society. 2013; $\quad$ http://www.bg-derm.org/wp-content/uploads/2013/06/02-Guideline-forbiologicals.pdf Accessed: 10/08/2014

26 Mrowietz U, Kragballe K, Reich K, Spuls P, Griffiths CE, Nast A et al. Definition of treatment goals for moderate to severe psoriasis: a European consensus. Arch Dermatol Res 2011; 303: 1-10.

27 Ormerod AD, Augustin M, Baker C, Chosidow O, Cohen AD, Dam TN et al. Challenges for synthesising data in a network of registries for systemic psoriasis therapies. Dermatology 2012; 224: 236-243.

28 Garcia-Doval I, Rustenbach SJ, Stern R, Dam TN, Cohen AD, Baker C et al. Systemic psoriasis therapy shows high between-country variation: a sign of unwarranted variation? Cross-sectional analysis of baseline data from the PSONET registries. Br J Dermatol 2013; 169: 710-714.

29 Lecluse LL, Naldi L, Stern RS, Spuls PI. National registries of systemic treatment for psoriasis and the European 'Psonet' initiative. Dermatology 2009; 218: 347-356.

30 Naldi L. on behalf of the Psonet network. The Psonet Collaboration. 9th ENCePP $\begin{array}{lllll}\text { Plenary } & \text { Meeting } & 2012 ; & & \text { May }\end{array}$ http://www.encepp.eu/publications/documents/3.2 Psonet.pdf Accessed: 10/08/2014

31 Augustin M, Glaeske G, Schafer I, Rustenbach SJ, Hoer A, Radtke MA. Processes of psoriasis health care in Germany--long-term analysis of data from the statutory health insurances. J Dtsch Dermatol Ges 2012; 10: 648-655.

32 Brodszky V, Baji P, Balogh O, Pentek M. Budget impact analysis of biosimilar infliximab (CT-P13) for the treatment of rheumatoid arthritis in six Central and Eastern European countries. Eur J Health Econ 2014; 15 Suppl 1: S65-71.

33 Laki J, Monok G, Palosi M, Gajdacsi JZ. Economical aspect of biological therapy in inflammatory conditions in Hungary. Expert Opin Biol Ther 2013; 13: 327-337. 
34 Gulacsi L, Rencz F, Pentek M, Brodszky V, Lopert R, Hever NV et al. Transferability of results of cost utility analyses for biologicals in inflammatory conditions for Central and Eastern European countries. Eur J Health Econ 2014; 15 Suppl 1: S27-34.

35 Gulacsi L, Pentek M. HTA in Central and Eastern European countries; the 2001: a space odyssey and efficiency gain. Eur J Health Econ 2014; 15: 675-680.

36 Feldman SR, Burudpakdee C, Gala S, Nanavaty M, Mallya UG. The economic burden of psoriasis: a systematic literature review. Expert Rev Pharmacoecon Outcomes Res 2014; 14: $685-705$.

37 Zhang W, Islam N, Ma C, Anis AH. Systematic Review of Cost-Effectiveness Analyses of Treatments for Psoriasis. Pharmacoeconomics 2014.

38 Agencja Oceny Technologii Medycznych. Wydział do Spraw Systemów Ochrony Zdrowia. Wniosek o objęcie refundacją leku Stelara (ustekinumab), $45 \mathrm{mg}$, w ramach programu lekowego: Leczenie cięzkiej postaci łuszczycy pospolitej z zastosowaniem $\begin{array}{llll}\text { ustekinumabu. } & \text { Analiza } & \text { weryfikacyjna 2012; }\end{array}$ http://www.aotm.gov.pl/bip/assets/files/zlecenia mz/2012/044/AWA/044 AWA DS 43305 Stelara luszczyca 2012.08.13.pdf Accessed: 12/12/2014

39 Gulacsi L, Rotar AM, Niewada M, Loblova O, Rencz F, Petrova G et al. Health technology assessment in Poland, the Czech Republic, Hungary, Romania and Bulgaria. Eur $J$ Health Econ 2014; 15 Suppl 1: S13-25.

40 Gniadecki R, Robertson D, Molta CT, Freundlich B, Pedersen R, Li W et al. Selfreported health outcomes in patients with psoriasis and psoriatic arthritis randomized to two etanercept regimens. J Eur Acad Dermatol Venereol 2012; 26: 1436-1443.

41 Luger TA, Barker J, Lambert J, Yang S, Robertson D, Foehl J et al. Sustained improvement in joint pain and nail symptoms with etanercept therapy in patients with moderate-to-severe psoriasis. J Eur Acad Dermatol Venereol 2009; 23: 896-904.

42 Shikiar R, Heffernan M, Langley RG, Willian MK, Okun MM, Revicki DA. Adalimumab treatment is associated with improvement in health-related quality of life in psoriasis: patient-reported outcomes from a phase II randomized controlled trial. $J$ Dermatolog Treat 2007; 18: 25-31. 
Table 1 Number of psoriasis patients treated with biologics annually in 6 CEE countries, 2014 or latest

\begin{tabular}{|l|l|l|l|l|l|l|l|l|}
\hline & $\begin{array}{l}\text { Estimated } \\
\text { number } \\
\text { of } \\
\text { psoriasis } \\
\text { patients }\end{array}$ & $\begin{array}{l}\text { Dermatology } \\
\text { centres } \\
\text { entitled to } \\
\text { administer } \\
\text { biologics }\end{array}$ & adalimumab & etanercept & infliximab & ustekinumab & Total & $\begin{array}{l}\text { Estimated } \\
\text { proportion } \\
\text { of patients } \\
\text { treated } \\
\text { with } \\
\text { biologics }\end{array}$ \\
\hline BGR & 145,691 & 3 & 8 & 15 & $60 * *$ & 2 & 85 & $0.06 \%$ \\
\hline CRO & 85,243 & 5 & 34 & 15 & 15 & 95 & 159 & $0.19 \%$ \\
\hline CZE & 210,323 & 18 & 540 & 270 & 96 & 282 & 1,188 & $0.56 \%$ \\
\hline HUN & 198,176 & 9 & 240 & 427 & 266 & 407 & $1,252 *$ & $0.63 \%$ \\
\hline POL & 770,666 & 38 & 114 & 16 & $\mathrm{NR}$ & 204 & 334 年 & $0.04 \%$ \\
\hline ROM & 400,401 & $\S \S$ & 584 & 623 & 366 & $\mathrm{NR}$ & 1,573 & $0.39 \%$ \\
\hline Total & $1,810,500$ & $>73$ & 1,520 & 1,366 & 803 & 990 & 4,591 & $0.25 \%$ \\
\hline
\end{tabular}

*Calculated by excluding the number of switchers.

** All biosimilar infliximab.

$\S$ Patient numbers for Poland cover the period between May, 2013 and August, 2014. Of note, total number of patients receiving biologics might be slightly higher due to other sources of financing such as diagnosis-related groups (DRG)-based.

$\S \S$ All dermatologists are allowed to prescribe biologics regardless of the centre.

NR: not reimbursed.

Population data (2013): Eurostat Statistics Database ${ }^{12}$

Number of patients: patient registries, health insurance databases, ministries of health, national professional societies

Prevalence of psoriasis: $2 \%$ (estimation).

BGR: Bulgaria, CRO: Croatia, CZE: Czech Republic, HUN: Hungary, POL: Poland, ROM: Romania 
Table 2 Disease burden of psoriasis in six Central and Eastern European countries

\begin{tabular}{|c|c|c|c|c|c|c|c|c|}
\hline Author, year & $\begin{array}{c}\text { Publication } \\
\text { type, language }\end{array}$ & Country & $\begin{array}{l}\text { Year } \\
\text { of } \\
\text { costs }\end{array}$ & Patients & Method & $\begin{array}{l}\text { Perspective of } \\
\text { costs } \\
\text { calculation }\end{array}$ & $\begin{array}{l}\text { Type of } \\
\text { costs } \\
\text { reported }\end{array}$ & $\begin{array}{c}\text { Average yearly cost per } \\
\text { patient (indirect costs } \\
\%)\end{array}$ \\
\hline $\begin{array}{l}\text { Balogh et al., } \\
2014^{18} *\end{array}$ & $\begin{array}{l}\text { full-text, } \\
\text { English }\end{array}$ & Hungary & 2012 & $\begin{array}{l}\mathrm{N}=200 \text {, moderate to severe } \\
\text { mean age } 51 \text { years } \\
\text { BST: } 51.5 \%\end{array}$ & $\begin{array}{l}\text { questionnaire } \\
\text { survey }\end{array}$ & societal & $\begin{array}{l}\text { direct and } \\
\text { indirect } \\
\text { (both HCA } \\
\text { and FCA) }\end{array}$ & $\begin{array}{l}\text { HCA: } \\
\text { NST } € 2,186(58 \%) \\
\text { TST } € 2,388(40 \%) \\
\text { BST } € 15,790(9 \%) \\
\text { FCA: } \\
\text { NST } € 1,132(18 \%) \\
\text { TST: } € 1,973(28 \%) \\
\text { BST: } € 14,562(1 \%)^{* *}\end{array}$ \\
\hline $\begin{array}{l}\text { Rencz et al., } \\
2014^{22 *}\end{array}$ & $\begin{array}{l}\text { full-text, } \\
\text { Hungarian }\end{array}$ & Hungary & 2012 & $\begin{array}{l}\mathrm{N}=57 \text {, moderate to severe } \\
\text { psoriasis with PsA } \\
\text { mean age: } 54 \text { years } \\
\text { BST: } 47 \%\end{array}$ & $\begin{array}{l}\text { questionnaire } \\
\text { survey }\end{array}$ & societal & $\begin{array}{l}\text { direct and } \\
\text { indirect } \\
(\mathrm{HCA})\end{array}$ & $\begin{array}{l}\text { NST } € 1,729(61 \%) \\
\text { TST } € 1,799(43 \%) \\
\text { BST } € 16,983(17 \%)^{* *}\end{array}$ \\
\hline $\begin{array}{l}\text { Petrikova et } \\
\text { al., } 2011^{20}\end{array}$ & $\begin{array}{l}\text { conference } \\
\text { paper, English }\end{array}$ & $\begin{array}{l}\text { Czech } \\
\text { Republic }\end{array}$ & NR & $\begin{array}{l}\mathrm{N}=259, \text { moderate to severe } \\
\text { mean age } 47 \text { years } \\
\text { BST: } 0 \%\end{array}$ & $\begin{array}{l}\text { questionnaire } \\
\text { survey }\end{array}$ & societal & $\begin{array}{l}\text { direct and } \\
\text { indirect } \\
\text { (FCA) }\end{array}$ & $\begin{array}{l}\text { with PsA } € 4,328(31 \%) \\
\text { without PsA } € 3,737 \\
(23 \%)\end{array}$ \\
\hline $\begin{array}{l}\text { Klimes - } \\
\text { Dolezal, } \\
2010^{19}\end{array}$ & $\begin{array}{l}\text { conference } \\
\text { paper, English }\end{array}$ & $\begin{array}{l}\text { Czech } \\
\text { Republic }\end{array}$ & 2009 & $\begin{array}{l}\mathrm{N}=179, \text { moderate to severe } \\
\text { mean age } 45 \text { years } \\
\text { BST: NR }\end{array}$ & $\begin{array}{l}\text { questionnaire } \\
\text { survey }\end{array}$ & governmental & $\begin{array}{l}\text { indirect } \\
\text { (FCA) }\end{array}$ & $\begin{array}{l}\text { absenteeism } € 214 \\
\text { part-time } € 168 \\
\text { fulltime disability } € 414\end{array}$ \\
\hline $\begin{array}{l}\text { Władysiuk et } \\
\text { al., } 2014^{21}\end{array}$ & $\begin{array}{l}\text { conference } \\
\text { paper, English }\end{array}$ & Poland & 2012 & $\begin{array}{l}\mathrm{N}=460 \text {, severity: } 6 \% \text { remission, } \\
54 \% \text { mild, } 29 \% \text { moderate, and } \\
12 \% \text { of high activity disease } \\
\text { age: } 18-65 \text { years, } \\
\text { BST: NR }\end{array}$ & $\begin{array}{l}\text { questionnaire } \\
\text { survey }\end{array}$ & societal & $\begin{array}{l}\text { indirect } \\
\text { (HCA) }\end{array}$ & $\begin{array}{l}\text { absenteeism } € 1,466 \\
\text { presenteeism } € 4,111^{\S}\end{array}$ \\
\hline
\end{tabular}

* same study, where the 57 patients with PsA is a subsample of the 200 patients analysed by Balogh et al. ${ }^{18}$; ** EUR $1=$ HUF $285 ; \S$ EUR $1=$ USD $1.34 ;$ BST: biological systemic therapy, FCA: friction cost approach; HCA: human capital approach; NR: not reported; NST: not receiving systemic therapy (topical treatment or none), PsA: psoriatic arthritis; TST: traditional systemic therapy 
Table 3 Biological and biosimilar therapy in psoriasis, reimbursement criteria and guidelines in 6 CEE countries

\begin{tabular}{|c|c|c|c|c|c|c|}
\hline & Bulgaria & Croatia & Czech Republic & Hungary & Poland & Romania \\
\hline $\begin{array}{l}\text { National/regional } \\
\text { registry of psoriasis } \\
\text { patients }\end{array}$ & No & $\begin{array}{c}\text { Registry owned by } \\
\text { National Referral } \\
\text { Centre for psoriasis }\end{array}$ & $\begin{array}{l}\text { Biorep* - includes } \\
\text { the majority of } \\
\text { insured patients on } \\
\text { biologics }\end{array}$ & $\begin{array}{l}\text { Insurance database } \\
\text { for patients on } \\
\text { biologics }\end{array}$ & $\begin{array}{c}\text { System of Monitoring } \\
\text { Therapeutic Programs } \\
\text { (SMPT) for patients on } \\
\text { biologics }\end{array}$ & No \\
\hline Reimbursement & $100 \%{ }^{\S}$ & $100 \%$ & $100 \%$ & $100 \%$ & $100 \%$ & $100 \%$ \\
\hline $\begin{array}{l}\text { Date from first } \\
\text { biological is } \\
\text { reimbursed for the } \\
\text { treatment of psoriasis }\end{array}$ & March 1, 2014 & Aug 10, 2014 & 2005 & March 2006 & January $1,2013^{* *}$ & June 2010 \\
\hline $\begin{array}{l}\text { Date from first } \\
\text { biosimilar is } \\
\text { reimbursed for the } \\
\text { treatment of psoriasis }\end{array}$ & March 1, 2014 & Not reimbursed & October, 2013 & May 15,2014 & Not reimbursed $* * *$ & April 1, 2014 \\
\hline $\begin{array}{l}\text { Clinical severity } \\
\text { criteria for being } \\
\text { eligible to start } \\
\text { reimbursed biological } \\
\text { therapy }\end{array}$ & PASI $>20$ or $\mathrm{BSA}>20$ & $\begin{array}{l}\text { PASI }>15 \text { and /or } \\
\text { BSA }>15 \\
\text { and/or DLQI }>15\end{array}$ & $\begin{array}{l}\text { PASI }>10 \text { and } \\
\text { DLQI }>10\end{array}$ & $\begin{array}{l}\text { PASI }>15 \text { and } \\
\text { DLQI }>10\end{array}$ & $\begin{array}{l}\mathrm{PASI}>18, \mathrm{DLQI}>10, \\
\text { and } \mathrm{BSA}>10 \$ \S\end{array}$ & $\begin{array}{l}\text { PASI } \geq 10 \text { and } \\
\text { DLQI } \geq 10\end{array}$ \\
\hline $\begin{array}{l}\text { Assessment of } \\
\text { effectiveness after the } \\
\text { initiation }\end{array}$ & $\begin{array}{l}\text { at week } 12 \text { and every } \\
6 \text { months afterwards }\end{array}$ & $\begin{array}{l}\text { at week } 12 \text { and at } \\
\text { week } 28\end{array}$ & at week 12 & between week $12-16$ & $\begin{array}{l}\text { at week } 4 \text {, and every } 12 \\
\text { weeks afterwards with } \\
\text { some additional drug } \\
\text { specific monitoring } \\
\text { activities }\end{array}$ & $\begin{array}{l}\text { at week } 12 \text { and every } \\
6 \text { month afterwards }\end{array}$ \\
\hline $\begin{array}{l}\text { Criteria of eligibility } \\
\text { for maintenance } \\
\text { therapy }\end{array}$ & $\begin{array}{l}\text { PASI improvement } \\
\geq 75 \% \text { or PASI } \\
\text { improvement } \geq 50 \% \\
\text { and DLQI } \\
\text { improvement } \geq 5 \\
\text { points }\end{array}$ & $\begin{array}{l}\text { at week 12: PASI } \\
\text { improvement } \geq 50 \% \\
\text { and DLQI } \\
\text { improvement } \geq 5 \\
\text { points } \\
\text { at week } 28 \text { : PASI } \\
\text { improvement } \geq 75 \% \\
\text { or PASI } \\
\text { improvement } \geq 50 \% \\
\text { and DLQI }\end{array}$ & $\begin{array}{l}\text { PASI improvement } \\
\geq 50 \%\end{array}$ & $\begin{array}{l}\text { PASI improvement } \\
\geq 50 \% \text { and DLQI } \\
\text { improvement } \geq 5 \\
\text { points }\end{array}$ & $\begin{array}{l}\text { PASI improvement } \\
\geq 50 \% \text { and DLQI } \\
\text { improvement } \geq 5 \text { points }\end{array}$ & $\begin{array}{l}\text { PASI improvement } \\
\geq 50 \% \text { and DLQI } \\
\text { improvement } \geq 5 \\
\text { points }\end{array}$ \\
\hline
\end{tabular}




\begin{tabular}{|c|c|c|c|c|c|c|}
\hline & & $\begin{array}{l}\text { improvement } \geq 5 \\
\text { points }\end{array}$ & & & & \\
\hline $\begin{array}{l}\text { Is the duration of } \\
\text { biological treatment } \\
\text { limited? }\end{array}$ & No & No & No & No & $\begin{array}{l}\text { Yes, adalimumab and } \\
\text { ustekinumab } 48 \text { weeks, } \\
\text { etanercept } 24 \text { weeks }\end{array}$ & No \\
\hline $\begin{array}{l}\text { Are biosimilars } \\
\text { allowed to use as a } \\
\text { first choice biological } \\
\text { treatment? }\end{array}$ & Yes & Not applicable & Yes & Yes & Not applicable ${ }^{\S \S \S}$ & Yes \\
\hline
\end{tabular}

BSA = body surface area; DRG = diagnosis-related group; DLQI = Dermatology Life Quality Index; PASI = Psoriasis Area and Severity Index

*http://www.biorep.cz

** DRG-based financing was started from April 6, 2011 and a Drug Program to finance biologics was established in January 1, 2013 with ustekinumab followed by adalimumab (July 1, 2013), and finally etanercept (November, 2014).

*** Biosimilars are available under DRG-based financing only.

$\S 75 \%$ is paid by the National Health Insurance Fund and $25 \%$ by the pharmaceutical company

$\S \S$ For DRG-based financing: PASI $>10$, DLQI $>10$, and BSA $>10$

$\S \S \S$ Yes, in DRG-based financing system 
Figure 1 Total health expenditure per capita and number of psoriasis patients treated with biologics per $10^{5}$ inhabitants in 6 selected CEE countries

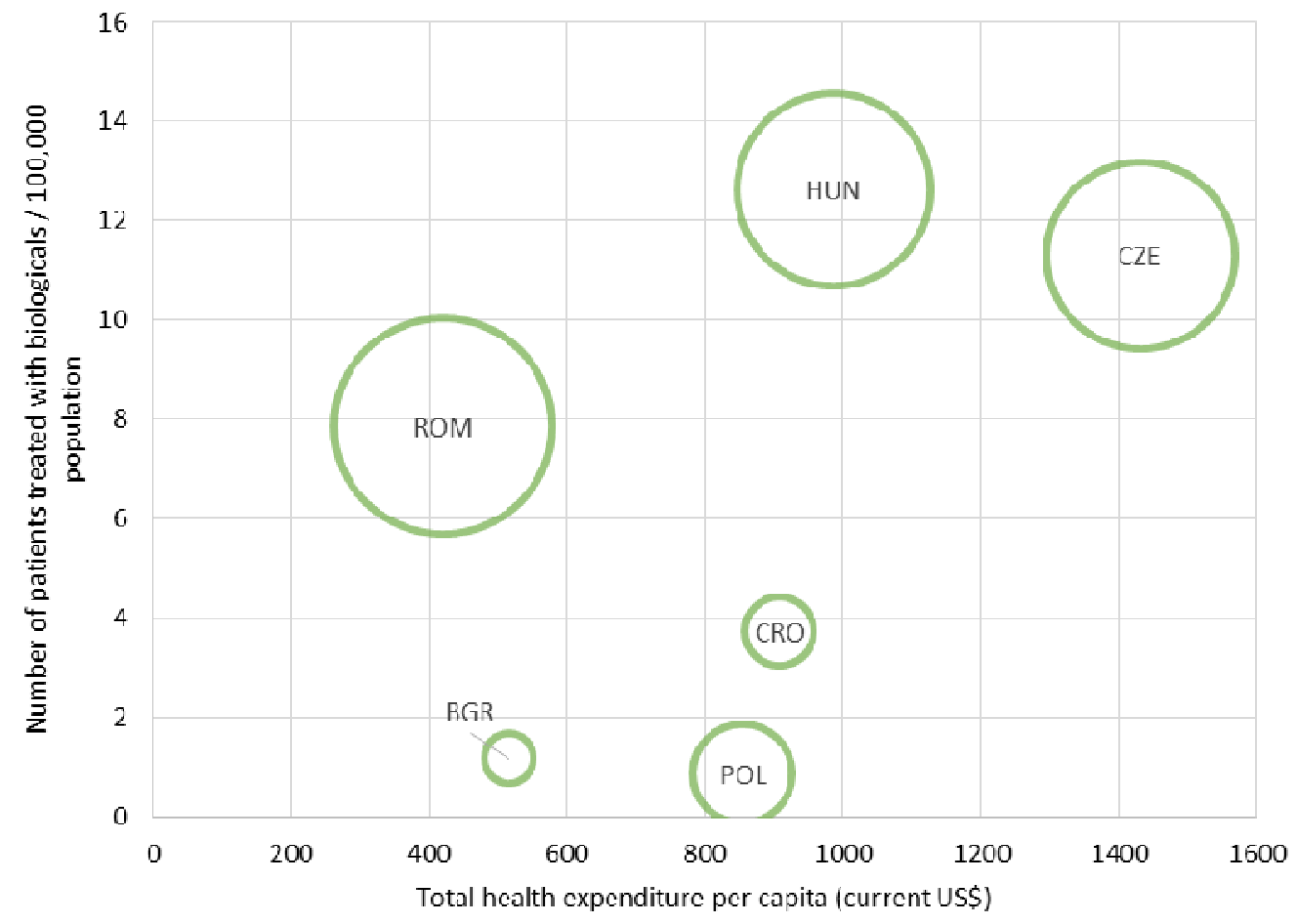

Sizes of bubbles refer to the absolute number of patients treated with biologics in each country. Patient number: patient registries, health insurance databases, ministries of health, national professional societies (2014 or latest)

Population data (2013): Eurostat Statistics Database ${ }^{12}$

Total health expenditure per capita (2012): World Bank Databank ${ }^{13}$

BGR: Bulgaria, CRO: Croatia, CZE: Czech Republic, HUN: Hungary, POL: Poland, ROM: Romania 
Authors are responsible for disclosing all financial and personal relationships between themselves and others that might be perceived by others as biasing their work. The JEADV Editors ask that all authors (not just the Corresponding Author) complete the following form.

For Co-authors: Please complete questions 4-10. Completed forms should be saved, and emailed as an attachment to the Corresponding Author.

For Corresponding Authors: Please complete all questions. It is the responsibility of the Corresponding Author to submit completed forms on behalf of all co-authors via Manuscript Central at the point of manuscript submission.

\title{
Corresponding author only (Co-authors go to Question 4):
}

POTENTIAL STUDY INTERPRETATION CONFLICTS

1. Some or all of the data that were used in this study were provided by a company with a vested interest in the product being studied.

2. The sponsor of this project had the right of commenting but the authors retained the right to accept or reject comments or suggestions.

3. The sponsor of this project had the right of final editing and/or approval of the manuscript submitted.

NO

\section{Corresponding author and Co-authors: POTENTIAL FINANCIAL CONFLICTS}

4. I, my spouse, or one of my dependent children is an employee of a company whose product is being studied.

5. I, my spouse, or one of my dependent children has significant equity interest (>USD10,000) in the company that owns the product being studied.

6. In the past three years I have:

\begin{abstract}
been paid as a consultant (or in a similar capacity) by a company with a vested interest in the product being studied, on issues related to the product being studied;

been paid as a consultant (or in a similar capacity) by a company with a vested interest in the product being studied, on issues unrelated to the product being studied;

received unrestricted research or educational support from a company with a vested interest in the product(s) being studied.
\end{abstract}

NO

If you have answered YES to any of the above questions, or if you have additional personal, commercial or academic conflicts of interest, please draft a statement to publish with the article. e.g., AB has been reimbursed by Safe Drugs Ltd. for international conference attendance.

8. Manuscript title

USE OF BIOLOGICS FOR PSORIASIS IN CENTRAL AND EASTERN EUROPE

9. Full name

Guenka Ivanova Petrova

0. In checking this box, I confirm I have completed this form to the best of my knowledge. 
Authors are responsible for disclosing all financial and personal relationships between themselves and others that might be perceived by others as biasing their work. The JEADV Editors ask that all authors (not just the Corresponding Author) complete the following form.

For Co-authors: Please complete questions 4-10. Completed forms should be saved, and emailed as an attachment to the Corresponding Author.

For Corresponding Authors: Please complete all questions. It is the responsibility of the Corresponding Author to submit completed forms on behalf of all co-authors via Manuscript Central at the point of manuscript submission.

\title{
Corresponding author only (Co-authors go to Question 4):
}

POTENTIAL STUDY INTERPRETATION CONFLICTS

1. Some or all of the data that were used in this study were provided by a company with a vested interest in the product being studied.

2. The sponsor of this project had the right of commenting but the authors retained the right to accept or reject comments or suggestions.

3. The sponsor of this project had the right of final editing and/or approval of the manuscript submitted.

NO

\section{Corresponding author and Co-authors: POTENTIAL FINANCIAL CONFLICTS}

4. I, my spouse, or one of my dependent children is an employee of a company whose product is being studied.

5. I, my spouse, or one of my dependent children has significant equity interest (>USD10,000) in the company that owns the product being studied.

6. In the past three years I have:

\begin{abstract}
been paid as a consultant (or in a similar capacity) by a company with a vested interest in the product being studied, on issues related to the product being studied;

been paid as a consultant (or in a similar capacity) by a company with a vested interest in the product being studied, on issues unrelated to the product being studied;

received unrestricted research or educational support from a company with a vested interest in the product(s) being studied.
\end{abstract}

If you have answered YES to any of the above questions, or if you have additional personal, commercial or academic conflicts of interest, please draft a statement to publish with the article. e.g., AB has been reimbursed by Safe Drugs Ltd. for international conference attendance.

George-Sorin Tiplica was speaker at national events or received unrestricted research or educational support from MSD, Abbvie, Johnson\&Johnson, Pfizer

8. Manuscript title

USE OF BIOLOGICS FOR PSORIASIS IN CENTRAL AND EASTERN EUROPE

9. Full name

George-Sorin Tiplica

10. In checking this box, I confirm I have completed this form to the best of my knowledge. 
25

26

27

29

30

31

33

34

35

36

37

38

39

40

41

43

44

45

46

47

48

49

51

52

53

54

55

57

58

59

60 \\ Page 25 of 38}

Journal of European Academy of Dermatology Venereology

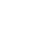

.

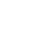

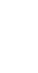

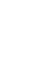

.


Authors are responsible for disclosing all financial and personal relationships between themselves and others that might be perceived by others as biasing their work. The JEADV Editors ask that all authors (not just the Corresponding Author) complete the following form.

For Co-authors: Please complete questions 4-10. Completed forms should be saved, and emailed as an attachment to the Corresponding Author.

For Corresponding Authors: Please complete all questions. It is the responsibility of the Corresponding Author to submit completed forms on behalf of all co-authors via Manuscript Central at the point of manuscript submission.

\title{
Corresponding author only (Co-authors go to Question 4):
}

POTENTIAL STUDY INTERPRETATION CONFLICTS

1. Some or all of the data that were used in this study were provided by a company with a vested interest in the product being studied.

2. The sponsor of this project had the right of commenting but the authors retained the right to accept or reject comments or suggestions.

3. The sponsor of this project had the right of final editing and/or approval of the manuscript submitted.

NO

\section{Corresponding author and Co-authors:} POTENTIAL FINANCIAL CONFLICTS

4. I, my spouse, or one of my dependent children is an employee of a company whose product is being studied.

5. I, my spouse, or one of my dependent children has significant equity interest (>USD10,000) in the company that owns the product being studied.

6. In the past three years I have:

\begin{abstract}
been paid as a consultant (or in a similar capacity) by a company with a vested interest in the product being studied, on issues related to the product being studied;

been paid as a consultant (or in a similar capacity) by a company with a vested interest in the product being studied, on issues unrelated to the product being studied;

received unrestricted research or educational support from a company with a vested interest in the product(s) being studied.
\end{abstract}

If you have answered YES to any of the above questions, or if you have additional personal, commercial or academic conflicts of interest, please draft a statement to publish with the article. e.g., AB has been reimbursed by Safe Drugs Ltd. for international conference attendance.

8. Manuscript title

Use of biologics for psoriasis in Central and Eastern Europe

Full name

Laszlo Gulacsi

0. In checking this box, I confirm I have completed this form to the best of my knowledge. 
Authors are responsible for disclosing all financial and personal relationships between themselves and others that might be perceived by others as biasing their work. The JEADV Editors ask that all authors (not just the Corresponding Author) complete the following form.

For Co-authors: Please complete questions 4-10. Completed forms should be saved, and emailed as an attachment to the Corresponding Author.

For Corresponding Authors: Please complete all questions. It is the responsibility of the Corresponding Author to submit completed forms on behalf of all co-authors via Manuscript Central at the point of manuscript submission.

\title{
Corresponding author only (Co-authors go to Question 4):
}

POTENTIAL STUDY INTERPRETATION CONFLICTS

1. Some or all of the data that were used in this study were provided by a company with a vested interest in the product being studied.

2. The sponsor of this project had the right of commenting but the authors retained the right to accept or reject comments or suggestions.

NO

3. The sponsor of this project had the right of final editing and/or approval of the manuscript submitted.

NO

\section{Corresponding author and Co-authors:} POTENTIAL FINANCIAL CONFLICTS

4. I, my spouse, or one of my dependent children is an employee of a company whose product is being studied.

5. I, my spouse, or one of my dependent children has significant equity interest (>USD10,000) in the company that owns the product being studied.

6. In the past three years I have:

\begin{abstract}
been paid as a consultant (or in a similar capacity) by a company with a vested interest in the product being studied, on issues related to the product being studied;

been paid as a consultant (or in a similar capacity) by a company with a vested interest in the product being studied, on issues unrelated to the product being studied;

received unrestricted research or educational support from a company with a vested interest in the product(s) being studied.
\end{abstract}

NO

7. A company whose product is being studied has provided funding to support the work on this project.

NO

If you have answered YES to any of the above questions, or if you have additional personal, commercial or academic conflicts of interest, please draft a statement to publish with the article. e.g., AB has been reimbursed by Safe Drugs Ltd. for international conference attendance.

8. Manuscript title

Use of biologics for psoriasis in Central and Eastern Europe

Full name

Lyubomir Trifonov Marinov

0. In checking this box, I confirm I have completed this form to the best of my knowledge. 
Authors are responsible for disclosing all financial and personal relationships between themselves and others that might be perceived by others as biasing their work. The JEADV Editors ask that all authors (not just the Corresponding Author) complete the following form.

For Co-authors: Please complete questions 4-10. Completed forms should be saved, and emailed as an attachment to the Corresponding Author.

For Corresponding Authors: Please complete all questions. It is the responsibility of the Corresponding Author to submit completed forms on behalf of all co-authors via Manuscript Central at the point of manuscript submission.

\title{
Corresponding author only (Co-authors go to Question 4):
}

POTENTIAL STUDY INTERPRETATION CONFLICTS

1. Some or all of the data that were used in this study were provided by a company with a vested interest in the product being studied.

2. The sponsor of this project had the right of commenting but the authors retained the right to accept or reject comments or suggestions.

3. The sponsor of this project had the right of final editing and/or approval of the manuscript submitted.

NO

\section{Corresponding author and Co-authors: POTENTIAL FINANCIAL CONFLICTS}

4. I, my spouse, or one of my dependent children is an employee of a company whose product is being studied.

5. I, my spouse, or one of my dependent children has significant equity interest (>USD10,000) in the company that owns the product being studied.

6. In the past three years I have:

\begin{abstract}
been paid as a consultant (or in a similar capacity) by a company with a vested interest in the product being studied, on issues related to the product being studied;

been paid as a consultant (or in a similar capacity) by a company with a vested interest in the product being studied, on issues unrelated to the product being studied;

received unrestricted research or educational support from a company with a vested interest in the product(s) being studied.
\end{abstract}

NO

If you have answered YES to any of the above questions, or if you have additional personal, commercial or academic conflicts of interest, please draft a statement to publish with the article. e.g., AB has been reimbursed by Safe Drugs Ltd. for international conference attendance.

8. Manuscript title

Use of biologics for psoriasis in Central and Eastern Eu...

9. Full name

Petr Arenberger

0. In checking this box, I confirm I have completed this form to the best of my knowledge. 
Authors are responsible for disclosing all financial and personal relationships between themselves and others that might be perceived by others as biasing their work. The JEADV Editors ask that all authors (not just the Corresponding Author) complete the following form.

For Co-authors: Please complete questions 4-10. Completed forms should be saved, and emailed as an attachment to the Corresponding Author.

For Corresponding Authors: Please complete all questions. It is the responsibility of the Corresponding Author to submit completed forms on behalf of all co-authors via Manuscript Central at the point of manuscript submission.

\title{
Corresponding author only (Co-authors go to Question 4):
}

POTENTIAL STUDY INTERPRETATION CONFLICTS

1. Some or all of the data that were used in this study were provided by a company with a vested interest in the product being studied.

2. The sponsor of this project had the right of commenting but the authors retained the right to accept or reject comments or suggestions.

3. The sponsor of this project had the right of final editing and/or approval of the manuscript submitted.

NO

\section{Corresponding author and Co-authors:} POTENTIAL FINANCIAL CONFLICTS

4. I, my spouse, or one of my dependent children is an employee of a company whose product is being studied.

5. I, my spouse, or one of my dependent children has significant equity interest (>USD10,000) in the company that owns the product being studied.

6. In the past three years I have:

\begin{abstract}
been paid as a consultant (or in a similar capacity) by a company with a vested interest in the product being studied, on issues related to the product being studied;

been paid as a consultant (or in a similar capacity) by a company with a vested interest in the product being studied, on issues unrelated to the product being studied;

received unrestricted research or educational support from a company with a vested interest in the product(s) being studied.
\end{abstract}

NO

If you have answered YES to any of the above questions, or if you have additional personal, commercial or academic conflicts of interest, please draft a statement to publish with the article. e.g., AB has been reimbursed by Safe Drugs Ltd. for international conference attendance.

8. Manuscript title

Use of biologics for psoriasis in Central and Eastern Europe

9. Full name

Witold Owczarek

10. In checking this box, I confirm I have completed this form to the best of my knowledge. 
Authors are responsible for disclosing all financial and personal relationships between themselves and others that might be perceived by others as biasing their work. The JEADV Editors ask that all authors (not just the Corresponding Author) complete the following form.

For Co-authors: Please complete questions 4-10. Completed forms should be saved, and emailed as an attachment to the Corresponding Author.

For Corresponding Authors: Please complete all questions. It is the responsibility of the Corresponding Author to submit completed forms on behalf of all co-authors via Manuscript Central at the point of manuscript submission.

\title{
Corresponding author only (Co-authors go to Question 4):
}

POTENTIAL STUDY INTERPRETATION CONFLICTS

1. Some or all of the data that were used in this study were provided by a company with a vested interest in the product being studied.

2. The sponsor of this project had the right of commenting but the authors retained the right to accept or reject comments or suggestions.

3. The sponsor of this project had the right of final editing and/or approval of the manuscript submitted.

NO

\section{Corresponding author and Co-authors:} POTENTIAL FINANCIAL CONFLICTS

4. I, my spouse, or one of my dependent children is an employee of a company whose product is being studied.

5. I, my spouse, or one of my dependent children has significant equity interest (>USD10,000) in the company that owns the product being studied.

6. In the past three years I have:

\begin{abstract}
been paid as a consultant (or in a similar capacity) by a company with a vested interest in the product being studied, on issues related to the product being studied;

been paid as a consultant (or in a similar capacity) by a company with a vested interest in the product being studied, on issues unrelated to the product being studied;

received unrestricted research or educational support from a company with a vested interest in the product(s) being studied.
\end{abstract}

If you have answered YES to any of the above questions, or if you have additional personal, commercial or academic conflicts of interest, please draft a statement to publish with the article. e.g., AB has been reimbursed by Safe Drugs Ltd. for international conference attendance.

8. Manuscript title

Use of biologics for psoriasis in Central and Eastern Europe

Full name

József Zsolt Gajdácsi Phd.

0. In checking this box, I confirm I have completed this form to the best of my knowledge. 
Authors are responsible for disclosing all financial and personal relationships between themselves and others that might be perceived by others as biasing their work. The JEADV Editors ask that all authors (not just the Corresponding Author) complete the following form.

For Co-authors: Please complete questions 4-10. Completed forms should be saved, and emailed as an attachment to the Corresponding Author.

For Corresponding Authors: Please complete all questions. It is the responsibility of the Corresponding Author to submit completed forms on behalf of all co-authors via Manuscript Central at the point of manuscript submission.

\title{
Corresponding author only (Co-authors go to Question 4):
}

POTENTIAL STUDY INTERPRETATION CONFLICTS

1. Some or all of the data that were used in this study were provided by a company with a vested interest in the

NO product being studied.

2. The sponsor of this project had the right of commenting but the authors retained the right to accept or reject comments or suggestions.

NO

3. The sponsor of this project had the right of final editing and/or approval of the manuscript submitted.

NO

\section{Corresponding author and Co-authors:} POTENTIAL FINANCIAL CONFLICTS

4. I, my spouse, or one of my dependent children is an employee of a company whose product is being studied.

5. I, my spouse, or one of my dependent children has significant equity interest (>USD10,000) in the company that owns the product being studied.

6. In the past three years I have:

\begin{abstract}
been paid as a consultant (or in a similar capacity) by a company with a vested interest in the product being studied, on issues related to the product being studied;

been paid as a consultant (or in a similar capacity) by a company with a vested interest in the product being studied, on issues unrelated to the product being studied;

received unrestricted research or educational support from a company with a vested interest in the product(s) being studied.
\end{abstract}

NO

If you have answered YES to any of the above questions, or if you have additional personal, commercial or academic conflicts of interest, please draft a statement to publish with the article. e.g., AB has been reimbursed by Safe Drugs Ltd. for international conference attendance.

8. Manuscript title

Use of biologics for psoriasis in Central and Eastern Europe

9. Full name

Márta Péntek

10. In checking this box, I confirm I have completed this form to the best of my knowledge. 
Authors are responsible for disclosing all financial and personal relationships between themselves and others that might be perceived by others as biasing their work. The JEADV Editors ask that all authors (not just the Corresponding Author) complete the following form.

For Co-authors: Please complete questions 4-10. Completed forms should be saved, and emailed as an attachment to the Corresponding Author.

For Corresponding Authors: Please complete all questions. It is the responsibility of the Corresponding Author to submit completed forms on behalf of all co-authors via Manuscript Central at the point of manuscript submission.

\title{
Corresponding author only (Co-authors go to Question 4):
}

POTENTIAL STUDY INTERPRETATION CONFLICTS

1. Some or all of the data that were used in this study were provided by a company with a vested interest in the product being studied.

2. The sponsor of this project had the right of commenting but the authors retained the right to accept or reject comments or suggestions.

3. The sponsor of this project had the right of final editing and/or approval of the manuscript submitted.

NO

\section{Corresponding author and Co-authors: POTENTIAL FINANCIAL CONFLICTS}

4. I, my spouse, or one of my dependent children is an employee of a company whose product is being studied.

5. I, my spouse, or one of my dependent children has significant equity interest (>USD10,000) in the company that owns the product being studied.

6. In the past three years I have:

\begin{abstract}
been paid as a consultant (or in a similar capacity) by a company with a vested interest in the product being studied, on issues related to the product being studied;

been paid as a consultant (or in a similar capacity) by a company with a vested interest in the product being studied, on issues unrelated to the product being studied;

received unrestricted research or educational support from a company with a vested interest in the product(s) being studied.
\end{abstract}

If you have answered YES to any of the above questions, or if you have additional personal, commercial or academic conflicts of interest, please draft a statement to publish with the article. e.g., AB has been reimbursed by Safe Drugs Ltd. for international conference attendance.

I have been paid by Janssen, MSD, Abbvie for professional presentations and lectures as well as for conusultations on preparation of health technology assessment reports and market access strategies.

8. Manuscript title

USE OF BIOLOGICS FOR PSORIASIS IN CENTRAL AND EASTERN E

9. Full name

Maciej Niewada

10. In checking this box, I confirm I have completed this form to the best of my knowledge. 
25

26

27

29

30

31

33

34

35

36

37

38

39

40

41

43

44

45

46

47

48

49

51

52

53

54

55

57

58

59

60 \\ Page 33 of 38}

Journal of European Academy of Dermatology Venereology

1

(1)

13

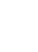

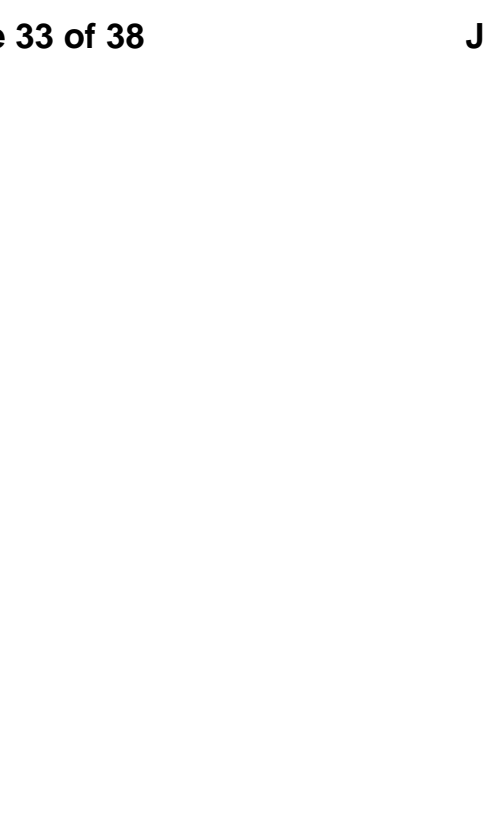

Jusmal of European Academy of Dermatology Venereology 
Authors are responsible for disclosing all financial and personal relationships between themselves and others that might be perceived by others as biasing their work. The JEADV Editors ask that all authors (not just the Corresponding Author) complete the following form.

For Co-authors: Please complete questions 4-10. Completed forms should be saved, and emailed as an attachment to the Corresponding Author.

For Corresponding Authors: Please complete all questions. It is the responsibility of the Corresponding Author to submit completed forms on behalf of all co-authors via Manuscript Central at the point of manuscript submission.

\section{Corresponding author only (Co-authors go to Question 4): \\ POTENTIAL STUDY INTERPRETATION CONFLICTS}

1. Some or all of the data that were used in this study were provided by a company with a vested interest in the product being studied. 2. The sponsor of this project had the right of commenting but the authors retained the right to accept or reject
comments or suggestions.

3. The sponsor of this project had the right of final editing and/or approval of the manuscript submitted.

\section{Corresponding author and Co-authors:}

POTENTIAL FINANCIAL CONFLICTS

4. I, my spouse, or one of my dependent children is an employee of a company whose product is being studied.

5. I, my spouse, or one of my dependent children has significant equity interest (>USD10,000) in the company that owns the product being studied.

6. In the past three years I have:

been paid as a consultant (or in a similar capacity) by a company with a vested interest in the product
being studied, on issues related to the product being studied;

been paid as a consultant (or in a similar capacity) by a company with a vested interest in the product being studied, on issues unrelated to the product being studied

received unrestricted research or educational support from a company with a vested interest in the

If you have answered YES to any of the above questions, or if you have additional personal, commercial or academic conflicts of interest, please draft a statement to publish with the article. e.g., AB has been reimbursed by Safe Drugs Ltd. for international
conference attendance.

Dr. L. Kemeny has been paid as a consultant of Janssen-Cilag, MSD, Pfizer Ltd., AbbVie Ltd.

8. Manuscript title

Use of biologics for psoriasis in Central and Eastern Europe

9. Full name

\section{LAJOS KEMENY}

10. In checking this box, I confirm I have completed this form to the best of my knowledge. 
Authors are responsible for disclosing all financial and personal relationships between themselves and others that might be perceived by others as biasing their work. The JEADV Editors ask that all authors (not just the Corresponding Author) complete the following form.

For Co-authors: Please complete questions 4-10. Completed forms should be saved, and emailed as an attachment to the Corresponding Author.

For Corresponding Authors: Please complete all questions. It is the responsibility of the Corresponding Author to submit completed forms on behalf of all co-authors via Manuscript Central at the point of manuscript submission.

\title{
Corresponding author only (Co-authors go to Question 4):
}

POTENTIAL STUDY INTERPRETATION CONFLICTS

1. Some or all of the data that were used in this study were provided by a company with a vested interest in the product being studied.

2. The sponsor of this project had the right of commenting but the authors retained the right to accept or reject comments or suggestions.

3. The sponsor of this project had the right of final editing and/or approval of the manuscript submitted.

NO

\section{Corresponding author and Co-authors:} POTENTIAL FINANCIAL CONFLICTS

4. I, my spouse, or one of my dependent children is an employee of a company whose product is being studied.

5. I, my spouse, or one of my dependent children has significant equity interest (>USD10,000) in the company that owns the product being studied.

6. In the past three years I have:

\begin{abstract}
been paid as a consultant (or in a similar capacity) by a company with a vested interest in the product being studied, on issues related to the product being studied;

been paid as a consultant (or in a similar capacity) by a company with a vested interest in the product being studied, on issues unrelated to the product being studied;

received unrestricted research or educational support from a company with a vested interest in the product(s) being studied.
\end{abstract}

If you have answered YES to any of the above questions, or if you have additional personal, commercial or academic conflicts of interest, please draft a statement to publish with the article. e.g., AB has been reimbursed by Safe Drugs Ltd. for international conference attendance.

Andrija Stanimirović has been reimbursed by companies Abbvie and Johnson\&Johnson for expert lectures,published professional materials and international conferences attendances

8. Manuscript title

USE OF BIOLOGICS FOR PSO IN CE AND EAST EUROPE COUNTRIES

9. Full name

Andrija Stanimirović

10. In checking this box, I confirm I have completed this form to the best of my knowledge. 
Authors are responsible for disclosing all financial and personal relationships between themselves and others that might be perceived by others as biasing their work. The JEADV Editors ask that all authors (not just the Corresponding Author) complete the following form.

For Co-authors: Please complete questions 4-10. Completed forms should be saved, and emailed as an attachment to the Corresponding Author.

For Corresponding Authors: Please complete all questions. It is the responsibility of the Corresponding Author to submit completed forms on behalf of all co-authors via Manuscript Central at the point of manuscript submission.

\title{
Corresponding author only (Co-authors go to Question 4):
}

POTENTIAL STUDY INTERPRETATION CONFLICTS

1. Some or all of the data that were used in this study were provided by a company with a vested interest in the product being studied.

2. The sponsor of this project had the right of commenting but the authors retained the right to accept or reject comments or suggestions.

3. The sponsor of this project had the right of final editing and/or approval of the manuscript submitted.

NO

\section{Corresponding author and Co-authors: POTENTIAL FINANCIAL CONFLICTS}

4. I, my spouse, or one of my dependent children is an employee of a company whose product is being studied.

5. I, my spouse, or one of my dependent children has significant equity interest (>USD10,000) in the company that owns the product being studied.

6. In the past three years I have:

\begin{abstract}
been paid as a consultant (or in a similar capacity) by a company with a vested interest in the product being studied, on issues related to the product being studied;

been paid as a consultant (or in a similar capacity) by a company with a vested interest in the product being studied, on issues unrelated to the product being studied;

received unrestricted research or educational support from a company with a vested interest in the product(s) being studied.
\end{abstract}

NO

If you have answered YES to any of the above questions, or if you have additional personal, commercial or academic conflicts of interest, please draft a statement to publish with the article. e.g., AB has been reimbursed by Safe Drugs Ltd. for international conference attendance.

8. Manuscript title

Use of biologics for psoriasis in Central and Eastern Europe

Full name

Valentin Brodszky

0. In checking this box, I confirm I have completed this form to the best of my knowledge. 
Authors are responsible for disclosing all financial and personal relationships between themselves and others that might be perceived by others as biasing their work. The JEADV Editors ask that all authors (not just the Corresponding Author) complete the following form.

For Co-authors: Please complete questions 4-10. Completed forms should be saved, and emailed as an attachment to the Corresponding Author.

For Corresponding Authors: Please complete all questions. It is the responsibility of the Corresponding Author to submit completed forms on behalf of all co-authors via Manuscript Central at the point of manuscript submission.

\title{
Corresponding author only (Co-authors go to Question 4):
}

POTENTIAL STUDY INTERPRETATION CONFLICTS

1. Some or all of the data that were used in this study were provided by a company with a vested interest in the product being studied.

2. The sponsor of this project had the right of commenting but the authors retained the right to accept or reject comments or suggestions.

3. The sponsor of this project had the right of final editing and/or approval of the manuscript submitted.

NO

\section{Corresponding author and Co-authors:} POTENTIAL FINANCIAL CONFLICTS

4. I, my spouse, or one of my dependent children is an employee of a company whose product is being studied.

5. I, my spouse, or one of my dependent children has significant equity interest (>USD10,000) in the company that owns the product being studied.

6. In the past three years I have:

\begin{abstract}
been paid as a consultant (or in a similar capacity) by a company with a vested interest in the product being studied, on issues related to the product being studied;

been paid as a consultant (or in a similar capacity) by a company with a vested interest in the product being studied, on issues unrelated to the product being studied;

received unrestricted research or educational support from a company with a vested interest in the product(s) being studied.
\end{abstract}

If you have answered YES to any of the above questions, or if you have additional personal, commercial or academic conflicts of interest, please draft a statement to publish with the article. e.g., AB has been reimbursed by Safe Drugs Ltd. for international conference attendance.

8. Manuscript title

Use of biologics for psoriasis in Central and Eastern Europe

Full name

Fanni Rencz

0. In checking this box, I confirm I have completed this form to the best of my knowledge. 